\title{
Implementasi SIG Untuk Monitoring Kesehatan Lingkungan Studi Kasus Kelurahan Harapan Baru
}

\author{
Husmul Beze* \\ Teknologi Rekayasa Perangkat \\ Lunak, Politeknik Pertanian Negeri \\ Samarinda, Samarinda \\ husmul@gmail.com \\ *Corresponding Author \\ Eva Nurmarini \\ Pengolahan Hasil Hutan Pertanian Negeri Samarinda, \\ Samarinda, \\ hamka@politanisamarinda.ac.id
}

\author{
Hamka \\ Prodi Teknologi Hasil Perkebunan, \\ Politeknik Pertanian Negeri \\ Samarinda, Samarinda \\ hamka@politanisamarinda.ac.id
}

\author{
Yulianto \\ Teknologi Rekayasa Perangkat \\ Lunak, Politeknik Pertanian Negeri \\ Samarinda, Samarinda \\ Yulianto.tile@yahoo.co.id
}

\begin{abstract}
Abstrak - Environmental health is an important factor in improving the health and well-being of human life and to prevent the dangers of disease. Environmental monitoring and engineering efforts need to be undertaken to meet these objectives. Harapan Baru Village is one of the villages in the Loa Janan Ilir District, Samarinda City, East Kalimantan Province. Harapan Baru Village is a fairly dense area. According to BPS data, Kota Samarinda in 2017 has a density of 4,304.34 inhabitants per $\mathrm{km} 2$. This kelurahan has problems in monitoring environmental health. Geographical information system (GIS) technology is currently developing rapidly. GIS can provide a monitoring model solution in environmental health countermeasures from a preventive side. For this reason, a study was conducted on environmental health monitoring in the Harapan Baru Village area using a web-based geographic information system. The method used to carry out the monitoring process is to use geographic information system tools, especially its spatial clustering analysis capabilities. The results showed that the GIS application of Environmental Health Monitoring in Harapan Baru was able to provide strong and up-to-date information about the environmental health conditions of residents. In particular, the system's ability to perform spatial queries by combining spatial and non-spatial attributes.
\end{abstract}

Kata Kunci- GIS, Web GIS, Environtment Health Monitoring, Harapan Baru

\section{PENDAHULUAN}

Peningkatan jumlah penduduk menyebabkan berkembangnya permukiman yang diikuti dengan pengelolaan yang tidak terkontrol khususnya di daerah perkotaan. Permukiman-permukiman dibangun dengan kualitas lingkungan yang rendah yang cenderung kurang terpadu, terarah, terencana, serta kurang memperhatikan

\author{
Heriad Daud Salusu \\ Pengolahan Hasil Hutan Pertanian Negeri Samarinda, \\ Samarinda \\ daud@politanisamarinda.ac.id
}

kelengkapan sarana dan prasarana dasar, seperti air bersih, sanitasi, sistem pengelolaan sampah, dan saluran pembuangan air hujan. Kesehatan lingkungan permukiman merupakan salah satu indikator untuk mengetahui tingkat kesejahteraan masyarakat di bidang sosial ekonomi (Adeline \& Widartono, 2012).

Padahal tujuan kesehatan lingkungan antara lain untuk melakukan koreksi, memperkecil/memodifikasi terjadinya bahaya dari lingkungan terhadap kesehatan serta kesejahteraan hidup manusia. Tujuan lainnya juga untuk pencegahan, mengefisienkan pengaturan berbagai sumber lingkungan untuk meningkatkan kesehatan dan juga kesejahteraan hidup manusia serta untuk menghindarkan dari bahaya penyakit. Ruang lingkup kesehatan lingkungan menurut WHO terdapat 17 unsur, beberapa diantaranya : penyediaan air minum, pengelolaan air buangan dan pengendalian pencemaran, pencegahan atau pengendalian pencemaran tanah oleh ekskreta manusia, perumahan \& pemukiman dan sebagainya.

Kelurahan Harapan Baru adalah salah satu kelurahan yang ada di Kecamatan Loa Janan Ilir Kota Samarinda Provinsi Kalimantan Timur. Kelurahan Harapan Baru memiliki luas sekitar 3,92 $\mathrm{Km}^{2}$. Menurut data BPS Kota Samarinda tahun 2017 Kelurahan Harapan Baru terbagi dalam 42 rukun tetangga (RT) dengan kepadatan 4.304,34 penduduk per $\mathrm{Km}^{2}$. Ujung tombak penjaga kesehatan di Kelurahan Harapan Baru adalah Puskesmas Kelurahan Harapan Baru. Program promotif dan preventif serta rehabilitatif sudah dijalankan oleh Puskesmas Harapan Baru untuk menjaga kesehatan masyarakat. Namun upaya yang dilakukan selama ini dianggap belum optimal. Persoalannya adalah belum adanya upaya monitoring masalah kesehatan tersebut. Permasalahan kesehatan ini bisa dikarenakan masalah kesehatan lingkungan yang menjadi sumber penyakit serta penyebaran penyakit (Anonim, 2017). 
Teknologi sistem informasi geografis (SIG) saat ini telah berkembang dengan cepat. Bahkan pemanfaatannya tidak hanya terbatas di bidang geografi saja tetapi telah merambah ke berbagai bidang, tidak terkecuali dalam bidang kesehatan. (Riner dkk dalam Rahmanti dan Prasetyo, 2012). Di bidang kesehatan, berbagai masalah kesehatan tidak serta merta dapat diatasi oleh satu disiplin ilmu saja, tetapi saat ini harus menggabungkan dari berbagai disiplin ilmu salah satunya sistem informasi geografis ini. SIG sangat berperan dalam penanggulangan penyakit dari sisi preventif. Salah satu kekuatan dari SIG yaitu analisis spatial clustering, dapat digunakan untuk mengetahui pola persebaran spasial suatu masalah yang kemudian dapat dianalisis hubungannya dengan faktor lingkungan. Teknologi ini juga dapat digunakan untuk mengetahui pola spasial pusat pelayanan kesehatan masyarakat sehingga dapat dijadikan bahan perencanaan pemilihan lokasi untuk pembangunan fasilitas pelayanan kesehatan yang baru.

Beze et al., (2016) menyatakan bahwa pengembangan sistem informasi geografis (SIG) berbasis web mampu memudahkan masyarakat dalam melakukan monitoring masalah-masalah yang berkaitan dengan kepentingan umum sebab aplikasi web mudah diakses masyarakat umum. Putri et al., (2014) juga menyatakan bahwa penyajian data secara geografis mampu memberikan gambaran atau perspektif berbeda dalam menyelesaikan masalah. Apalagi SIG yang dikembangkan dipadupadankan antara basisdata spasial dan non spasial maka mampu memberikan informasi terkini dan kuat untuk menyelesaikan sebuah masalah.

Dengan alasan di atas maka dilakukan penelitian tentang monitoring kesehatan lingkungan di daerah Kelurahan Harapan Baru menggunakan sistem informasi geografis berbasis web. Khususnya monitoring kesehatan lingkungan pada penyediaan air minum, ketersediaan dan jenis pembuangan limbah manusia. Tujuan penelitian ini antara lain adalah

1. Membuat peta sebaran penggunaan jamban dan sumber air warga di Kelurahan Harapan Baru Kota Samarinda.

2. Mengembangkan sistem informasi geografis berbasis web agar mudah diakses oleh masyarakat umum

3. Mengembangkan basisdata pendukung sistem informasi geografis kesehatan ini

Diharapkan hasil penelitian ini mampu memberikan informasi tentang kondisi kesehatan lingkungan di Kelurahan Harapan Baru khususnya tentang sebaran jenis jamban dan sumber air bersih warga. Selain itu diharapkan penelitian ini bisa digunakan oleh Pemerintah Kota Samarinda, khususnya Puskesmas Harapan Baru untuk memonitor kondisi kesehatan lingkungan di Kelurahan Harapan Baru secara lebih akurat dengan adanya updating data secara realtime.

\section{METODE PENELITIAN}

Penelitian ini dilakukan di Laboratorium Geomatika Politeknik Pertanian Negeri Samarinda dan Kelurahan di RT 25 Kelurahan Harapan Baru Kecamatan Loa Janan Ilir sebagai obyek yang dikaji. Penelitian ini memerlukan waktu selama 6 bulan, terhitung dari bulan Oktober 2017 hingga Juni 2018 meliputi studi pustaka, identifikasi masalah, penentuan metode penelitian, pengambilan data lapang, analisa data, pengembangan sistem, evaluasi dan dokumentasi.

Adapun alat yang digunakan dalam kegiatan ini antara lain GPS Navigasi Garmin 60CSx, perangkat lunak mapsource, global mapper, QuantumGIS, Notepad ++, Browser, Framework Laravel,dan Leafletjs dan kamera. Bahan yang digunakan diantaranya alat tulis, citra dari openstreetmap sebagai peta dasar, Peta Administrasi Kelurahan Harapan Baru milik Bappeda Kota Samarinda tahun 2013, kuisioner.

Untuk memudahkan proses pengembangan aplikasi maka digunakan metode prototipe seperti yang tergambar pada diagram di bawah ini.

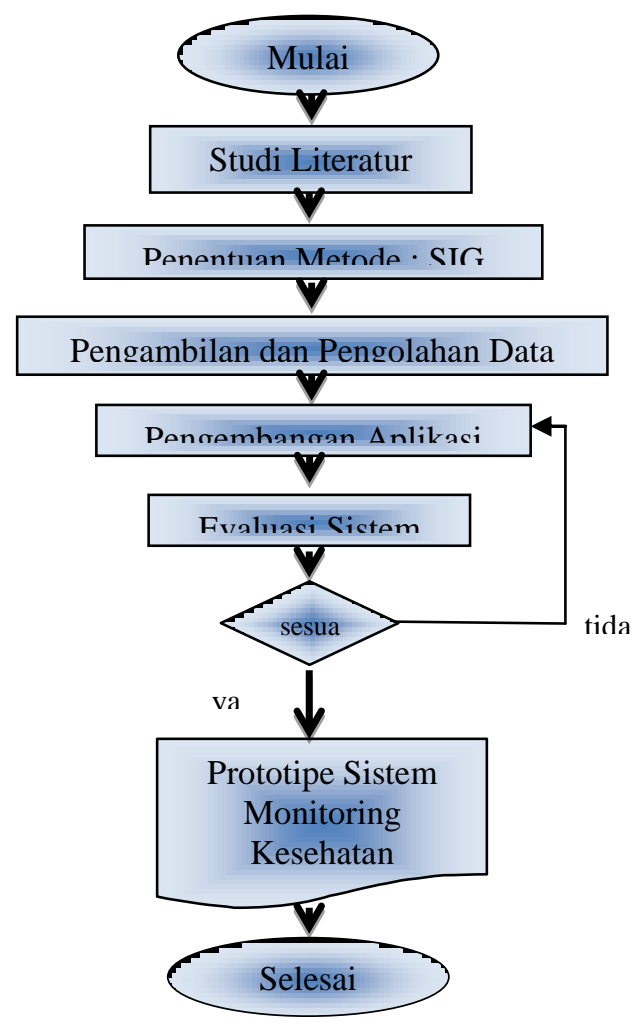

Gambar 1. Diagram Alir Prosedur Penelitian

Metode yang digunakan untuk melakukan monitoring kesehatan lingkungan di Kelurahan Harapan Baru adalah menggunakan tool SIG dengan memanfaatkan kemampuan SIG melakukan analisa spasial clustering. Ada dua hasil clustering dalam penelitian ini yaitu:

1. Clustering penggunaan jamban. Ada tiga cluster yang dihasilkan dalam penggunaan jamban yakni warga dengan jamban leher angsa/kloset, warga dengan 
jamban cemplung dan warga yang tidak memiliki jamban pribadi

2. Clustering penggunaan sumber air. Juga ada tiga kategori yang digunakan dalam cluster sumber air yakni sumber air dari PDAM, air sungai dan sumur.

Secara umum data yang digunakan dalam penelitian ini terbagi menjadi dua yaitu data spasial dan data non spasial. Data spasial terdiri dari tiga tabel yaitu :

1. Tabel data point koordinat rumah: idRumah, koordinatRumah

2. Tabel data jalan : idJalan, namaJalan, koordinatJalan

3. Tabel data poligon Batas RT/Kelurahan : idRT/idKelurahan, namaKelurahan,

koordinatKelurahan

Sementara itu tabel data non spasial yang digunakan dalam penelitian ini antara lain :

1. Tabel data rumah : id, nomor, namaPemilik

2. Tabel data penghuni : id, idRumah, namaKepalaKeluarga, NIK, noKartuKeluarga

3. Tabel data jamban : id, idRumah, jenisJamban (Jongkok/Cemplung/Tidak Punya)

4. Tabel data sumber air : id, idRumah, sumberAir

Selain data di atas, sistem yang dikembangkan dalam penelitian ini juga memuat dan mengatur data registrasi pengguna, login pengguna dan pengaturan tingkatan pengguna. Tabel yang digunakan dalam pengaturan pengguna ini antara lain :

1. User : id, name, email, password, token

2. Role : id, name, display_name, description

3. Permission : id, name, display_name, description

\section{HASIL DAN PEMBAHASAN}

HASIL

Ada empat bagian yang dikembangkan dalam aplikasi monitoring kesehatan lingkungan ini yaitu sistem masukan, basisdata, proses dan keluaran.

1. Sistem Masukan

Sistem masukan data dilakukan terpisah yaitu masukan data spasial dan non spasial. Sistem masukan data spasial dilakukan dengan menggunakan bantuan aplikasi Quantum GIS. Data spasial dengan tipe point, line maupun polygon dikelola dibuat, dikelola dan dimanajemen menggunakan aplikasi open source ini. Selain disimpan dalam bentuk shapefile, data spasial ini juga disimpan dalam bentuk geoJson.

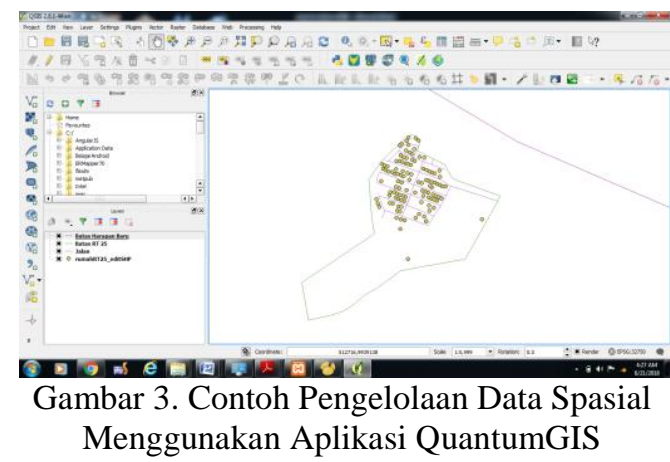

Sementara sistem masukan data non spasial dikembangkan menggunakan framework laravel. Setiap tabel data, baik tabel data rumah, tabel jenis jamban warga dan tabel sumber air warga akan dibuatkan fitur buat data, tampil data, edit data dan hapus data. Fitur-fitur tersebut dikembangkan berdasarkan hasil diskusi dengan pihak pengguna yaitu Puskesmas Harapan Baru. Selanjutnya data non spasial ini disimpan dalam basisdata relasional menggunakan aplikasi MySQL. Adapun contoh tampilan sistem masukan ini bisa dilihat pada Gambar 4 dan Gambar 5.

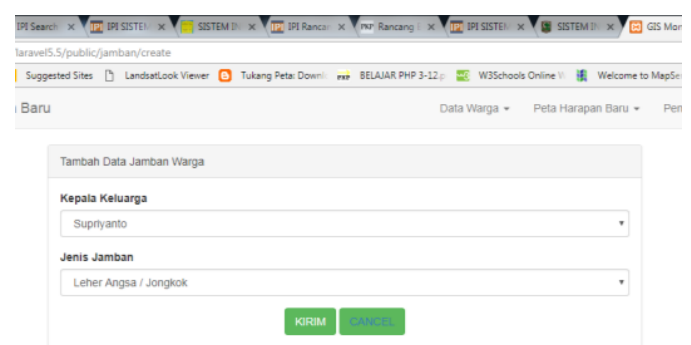

Gambar 4. Fitur Menambah Data Warga dengan Jenis Jamban yang Dimilikinya

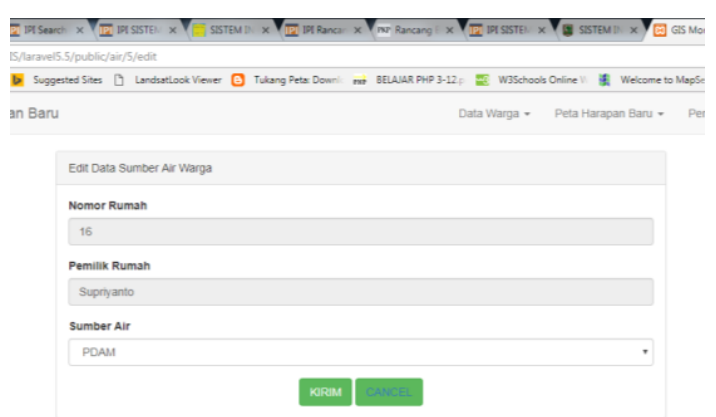

Gambar 5. Edit Data Sumber Air Rumah Warga

Selain mengembangkan tampilan sistem masukan dua data di atas, dalam aplikasi ini juga disediakan fitur untuk sistem masukan untuk login. Sebab dalam aplikasi ini, pengguna dibedakan dalam tiga kategori yaitu admin, operator dan user. Sistem masukan register dan login dalam aplikasi ini dikembangkan dengan memanfaatkan fasilitas yang dimiliki oleh framework laravel. Sementara pengaturan tingkatan pengguna dikembangkan dengan memanfaatkan fasilitas pihak ketiga yaitu zizacolentrust.

\section{Basisdata}

Basisdata aplikasi ini dikembangkan pada aplikasi ini adalah sistem manajemen data relasional yaitu MySQL. Rancangan fisik basisdata aplikasi ini terbagi dua yaitu basisdata spasial dan non spasial. Data spasial terdiri dari tipe data titik rumah warga, tipe data garis jalan dan tipe data poligon batas kelurahan. Ketiga data tersebut disimpan dalam format shapefile dan geoJson dan diletakan di dalam folder public/data.

Data non spasial dikembangkan di aplikasi MySQL dengan dua kelompok relasi. Adapun rancangan fisik data non spasial selengkapnya bisa dilihat pada Gambar 9 dan Gambar 10 di bawah ini. 


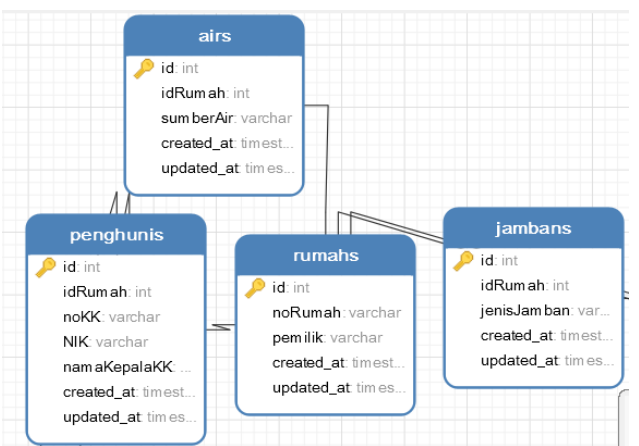

Gambar 6. Rancangan Fisik Data Rumah, Jenis Jamban dan Sumber Air

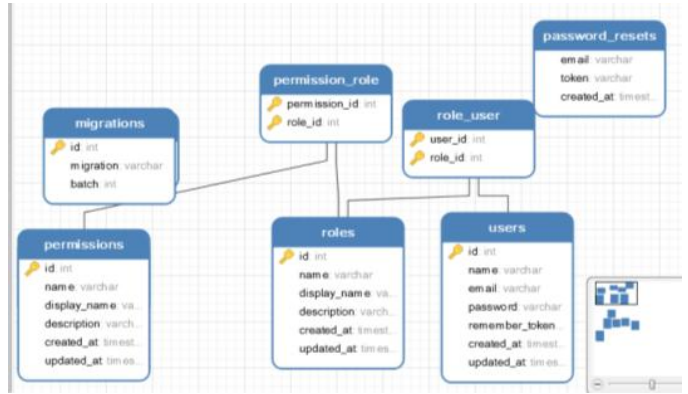

Gambar 7. Racangan Fisik Data User, Role dan Permission

3. Sistem Proses

Secara garis besar ada dua proses yang dilakukan di dalam pengembangan sistem yaitu proses pengolahan data spasial dan proses pengolahan data non spasial. Dua proses ini dibedakan dengan maksud untuk memudahkan dalam pengembangan dan jalannya aplikasi. Adapun proses aliran data yang terjadi dalam aplikasi bisa dilihat pada Gambar 8 berikut:

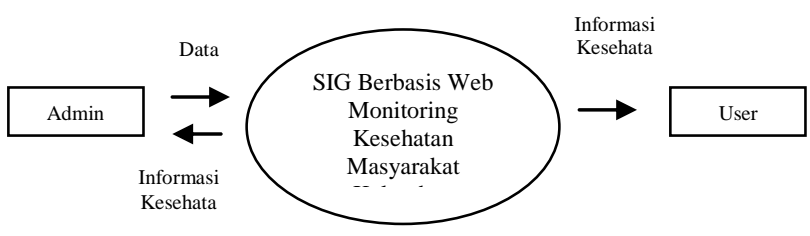

Gambar 8. Diagram Konteks SIG Berbasis Web Monitoring Kesehatan Masyarakat Kelurahan Harapan Baru

4. Sistem Keluaran Keluaran

Sama dengan sistem masukan, sistem keluaran yang dikembangkan pada aplikasi juga dibedakan menjadi dua yaitu sistem keluaran data spasial dan keluaran data non spasial. Sistem keluaran data spasial menampilkan peta sebaran rumah warga, peta sebaran sumber air yang digunakan warga dan peta sebaran jenis jamban yang digunakan warga.

Sistem keluaran data non spasial terdiri dari fitur data rumah, data penghuni, data sumber air warga dan data jenis jamban yang digunakan. Semua data tersebut ditampilkan dalam bentuk tabulasi.

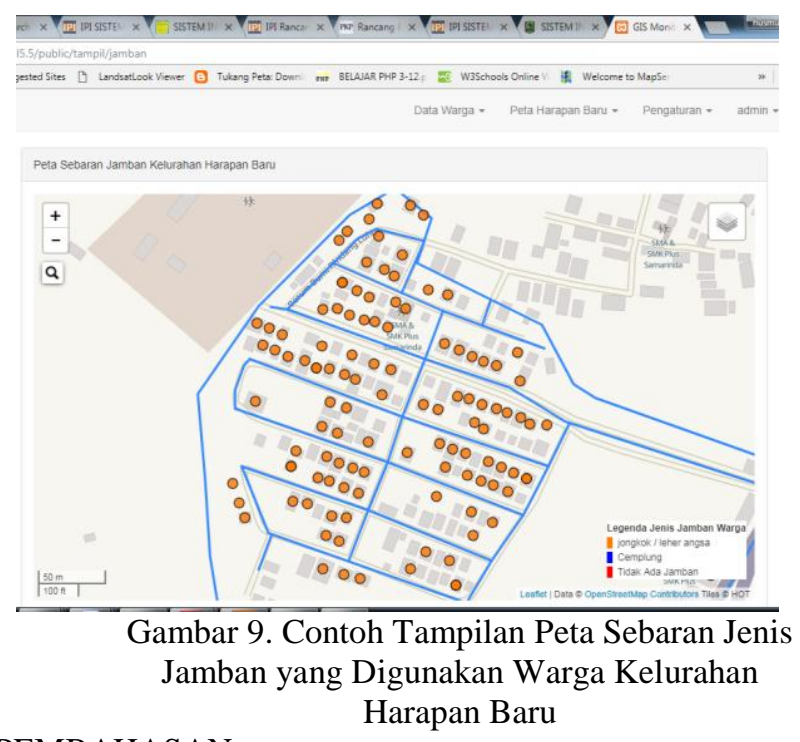

PEMBAHASAN

1. Sistem Masukan

Dalam Aplikasi Monitoring Kesehatan Lingkungan Kelurahan Harapan Baru ini penanganan data spasial dilakukan terpisah dengan data non spasial. Penanganan data spasial dilakukan menggunakan aplikasi Quantum GIS. Hal ini dimaksudkan untuk lebih mempermudah pengelolaan data spasial. Pengelolaan data menggunakan aplikasi Quantum GIS bisa dilakukan secara visual. Sehingga proses penambahan data, editing data ataupun penghapusan data bisa dilakukan dengan lebih mudah. Jika pengelolaan data dilakukan menggunakan aplikasi sendiri dan berbasis text maka proses pengelolaan datanya akan sangat sulit. Khususnya untuk pengelolaan tipe data garis dan poligon. Tipe data vector garis dan poligon memiliki karakteristik dengan jumlah node (titik sambung) yang tidak bisa diprediksi jumlahnya. Sehingga akan mengalami kesulitan jika pengelolaannya dilakukan dengan berbasis teks. Namun akan mudah dilakukan jika dilakukan pengelolaan berbasis visual.

2. Basisdata

Sama dengan sistem masukan, pengelolaan basisdata juga dilakukan terpisah antara data spasial dan non spasial. Data spasial diletakan di dalam folder. Sementara non spasial dikelola dalam sebuah sistem basisdata relasional, MySQL. Hal ini dimaksudkan untuk mempermudah pengelolaan data. Data spasial yang diletakan di dalam folder disimpan dalam format geoJson. Menurut keterangan dari pengembang library leafletjs, penyimpanan data spasial dalam format geoJson akan meningkatkan performa kecepatan menampilkan data dibandingkan dengan menyimpan data dengan format shapefile.

3. Sistem Proses

Tidak berbeda dengan sistem masukan, pada sistem proses ini aliran data juga dibagi menjadi dua yaitu proses aliran data spasial dan non spasial. Dua aliran data ini dipertemukan dalam query untuk menampilkan data spasial rumah warga dengan jenis jamban serta sumber air yang digunakan. 
Adanya proses gabungan data spasial dan non spasial lewat query ini membuat tampilan SIG menjadi lebih kuat dan lebih mudah dipahami pengguna. Apalagi data spasial yang digunakan bisa diupdate sesuai dengan perkembangan keadaan. Sehingga data yang ditampilkan aplikasi seperti data realtime.

4. Sistem Keluaran

Tampilan keluaran aplikasi SIG sudah cukup lengkap. Selain tubuh peta, tampilan peta yang dikembangkan sudah dilengkapi dengan panel perbesaran dan perkecilan, panel pencarian data penghuni rumah, skala, legenda dan pilihan tampilan data spasial. Untuk membedakan jenis air yang digunakan di setiap rumah warga, maka digunakan warna berbeda pada tiap kluster. Jika di rumah warga tersebut menggunakan sumber air dari perusahaan air minum (PDAM) maka warna point rumah warga akan berwarna orange. Jika rumah warga menggunakan air sumur sebagai sumber airnya maka peta akan menampilkan titik dengan warga biru. Sementara titik dengan warga merah menunjukan bahwa rumah warga di titik itu menggunakan sungai sebagai sumber airnya. Penggunaan warna berbeda tersebut merupakan hasil dari query yang menggabungkan antara data spasial dengan non spasial antara data koordinat rumah warga, data pemilik data, data penghuni warga dan data penggunaan sumber air. Dalam aplikasi, setiap titik juga dilengkapi dengan fitur popup. Misalnya peta sebaran sumber air, maka fitur popup-nya adalah nama penghuni rumah dan jenis jamban yang digunakan. Begitu juga sebaliknya, jika peta yang ditampilkan adalah peta sebaran jenis jamban maka fitur popup-nya adalah data nama penghuni dan sumber air yang digunakan. Adanya fitur popup ini membuat informasi data SIG yang diberikan semakin lengkap dan memudahkan pengguna membuat keputusan, khususnya bagi Puskesmas Harapan Baru dalam menjalankan program kesehatannya.

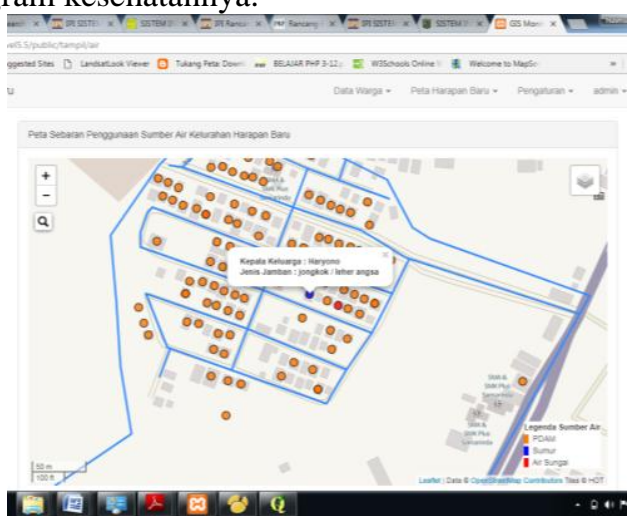

Gambar 10. Contoh Tampilan Hasil Query dan Fitur Popup yang Dimiliki Aplikasi

\section{KESIMPULAN}

1. Peta Monitoring Kesehatan Lingkungan di Harapan Baru yang dikembangkan mampu memberikan informasi yang kuat dan terkini tentang kondisi warga

2. Pengembangan aplikasi monitoring menggunakan sistem informasi geografis dan berbasis web memudahkan warga untuk memahami dan mengakses informasi yang diberikan aplikasi.

3. Pengembangan basisdata non spasial yang dimiliki aplikasi mampu memperkuat query yang dilakukan sehingga memperkaya informasi yang disampaikan.

\section{DAFTAR PUSTAKA}

Adeline, V., \& Widartono, B. S. (2012). PENGGUNAAN CITRA QUICKBIRD DAN SISTEM INFORMASI GEOGRAFIS UNTUK PEMETAAN KESEHATAN LINGKUNGAN PERMUKIMAN (Kasus di Kecamatan Rawa Lumbu, Bekasi). Jurnal Bumi Indonesia, 1(2), 131-139.

http://lib.geo.ugm.ac.id/ojs/index.php/jbi/article/view/18

Anonim. 2017. Samarinda Dalam Angka. BPS Kota Samarinda. www.samarindakota.bps.go.id

Beze, H., Kamasiah, \& Mardiana. (2016). Pengembangan Sig Berbasis Web Pada Tutupan Hutan Kota Studi Kasus Kecamatan Samarinda Seberang dan Palaran. Jurnal Digit, 6(1), 37-46.

http://jurnaldigit.org/index.php/DIGIT/article/view/37

Putri, G. A. S., Sudarsono, B., \& Wijaya, A. P. (2014). Rancang Bangun Sistem Informasi Geografis Pelayanan Kesehatan Masyarakat Berbasis Web (Studi Kasus: Kota Semarang). Jurnal Geodesi Undip, 3(1), 275-288. https://ejournal3.undip.ac.id/index.php/geodesi/article/vie w/4729 